\title{
GAYA KEPEMIMPINAN MEMPENGARUHI KINERJA ANGGOTA ORGANISASI
}

\author{
I Nyoman Artayasa \\ Fakultas Ilmu Sosial dan Ilmu Politik Universitas Mahendradatta \\ Nyomanartayasa66@gmail.com
}

\begin{abstract}
Abstrak - Gaya Kepemimpinan Dalam Organisasi adalah untuk mengetahui bagaimana cara memimpin sebuah kelompok atau organisasi. Selain itu juga dapat mengetahui pengaruh dari gaya-gaya kepemimpinan yang digunakan oleh seorang pemimpin dalam menghadapi situasi dan kondisi tertentu. Terdapat berbagai macam gaya-gaya memimpin. Semua gaya kepemimpinan itu masing-masing memiliki ciri tersendiri dan itulah yang menjadikan seorang pemimpin dapat memimpin kelompoknya dengan caranya sendiri yang pastinya akan bertujuan sama seperti pemimpin pada umumnya yang ingin mempengaruhi orang untuk melakukan tindakan yang bermanfaat bagi organisasi dan dirinya sendiri untuk mencapai tujuan tertentu.Apapun bentuk gaya kepemimpinannya akan mempengaruhi cara orang bekerja sebagai individu atau sebagai kelompok. Dalam kenyataannya pemimpin dapat mempengaruhi semangat dan kegairahan kerja, keamanan, kualitas kehidupan kerja dan terutama tingkat prestasi suatu organisasi
\end{abstract}

Kata kunci: gaya, kepemimpinan, organisasi.

\begin{abstract}
Leadership Style In Organization is to know how to lead a group or organization.It can also know the influence of leadership styles used by a leader in dealing with certain situations and conditions. There are a wide range of lead styles. All of these leadership styles each have their own traits and that's what makes a leader able to lead his or her group in his or her own way that will surely aim just like a leader in general who wants to influence people to take actions that benefit the organization and itself to achieve certain goals. Whatever form his leadership style will affect the way people work as individuals or as a group.In reality leaders can influence the spirit and excitement of work, security, quality of working life and especially the level of achievement of an organization
\end{abstract}

Keywords: style, leadership, organization.

\section{PENDAHULUAN}

\section{A. Latar Belakang.}

Keberadaan seorang pemimpin dalam organisasi sangat dibutuhkan untuk membawa organisasi kepada tujuan yang telah ditetapkan. Berbagai gaya kepemimpinan akan mewarnai perilaku seorang pemimpin dalam menjalankan tugasnya. Bagaimanapun gaya kepemimpinan seseorang tentunya akan diarahkan untuk kepentingan bersama yaitu kepentingan anggota dan organisasi. Kepemimpinan seseorang dapat mencerminkan karakter pribadinya.

Pemimpin dan Kepemimpinan merupakan suatu kesatuan kata yang tidak 
dapat dipisahkan secara struktural maupun fungsional. Beberapa pengertianpengertian mengenai pemimpin dan kepemimpinan, sebagai berikut :

1. Tikno Lensufie dalam bukunya yang berjudul

"Leadership untuk Profesional dan Mahasiswa" memberikan pengertian pemimpin sebagai seseorang yang mampu menggerakkan pengikut untuk mencapai tujuan organisasi.

2. Moejiono (2002) memandang bahwa leadership tersebut sebenarnya sebagai akibat pengaruh satu arah, karena pemimpin mungkin memiliki kualitas-kualitas tertentu yang membedakan dirinya dengan pengikutnya. Para ahli teori sukarela (compliance induction theorist) cenderung memandang leadership sebagai pemaksaan atau pendesakan pengaruh secara tidak langsung dan sebagai sarana untuk membentuk kelompok sesuai dengan keinginan pemimpin (Moejiono, 2002).

\section{Ralph M. Stogdill dalam Sutarto} (1998b:13)Kepemimpinan adalah suatu proses mempengaruhi kegiatankegiatan sekelompok orang yang terorganisasi dalam usaha mereka menetapkan dan mencapai tujuan.

4. Sutarto (1998b:25) Kepemimpinan adalah rangkaian kegiatan penataan berupa kemampuan mempengaruhi perilaku orang lain dalam situasi tertentu agar bersedia bekerja sama untuk mencapai tujuan yang telah ditetapkan.
Dalam suatu organisasi baik itu pemerintah maupun swasta, para karyawan dalam pelaksanaan tugasnya pencapaiannya bisa berbeda beda, tergantung dari siapa yang memimpin. Setiap pemimpin mempunyai gaya memimpin yang berbeda-beda. Hal ini menunjukan bahwa gaya kepemimpinan mempunyai korelasi dengan kinerja pegawai.

\section{B. Permasalahan}

Berdasarkan uraian di atas, permasalahan yang dihadapi adalah sebagai berikut :

1. Gaya kepemimpinan yang bagaimana dapat meningkatkan kinerja pegawai dalam organisasi?

2. Gaya kepemimpinan yang bagaimana yang diharapkan dalam organisasi?

\section{TINJAUAN PUSTAKA}

A. Pengertian Kepemimpinan

1. Kepeminpinan adalah : pengaruh antar pribadi yang dijalankan dalan suatu situasi tertentu, serta diarahkan melalui proses komunikasi ke arah satu atau beberapa tujuan tertentu ( Wescler dan Nassarik,1961 )

2. Kepemimpinan adalah prilaku dari seorang individu yang memimpin aktifitas suatu kelompok ke suatu tujuan yang ingin dicapai bersama ( Hemhiel and coons, 1957 )

3. Kepemimpinan adalah proses mempengaruhi aktifitas-aktifitas sebuah kelompok yang diorganisasikan ke arah pencapaian tujuan ( Rauch and Behling, 1984)

4. Kepemimpinan adalah sebuah proses memberi arti ( pengarahan yang berarti) thd usaha kolektif dan yang 


\author{
mengakibatkan kesediaan untuk \\ melakukan usaha yang diinginkan \\ untuk mencapai sasaran (Jacobs and \\ Jacques, 1990)
}

\section{B. Fungsi Kepemimpinan}

Fungsi kepemimpinan dalam manajemen adalah suatu cara yang dilakukan oleh seorang pemimpin agar dapat menambah nilai pada suatu kelompok. Suatu kepemimpinan akan mampu menjalankan fungsinya dengan baik, jika pemimpin di dalamnya memiliki dominasi yang kuat terhadap kelompok sosial lainnya. Diambil dari website STUDiLMU editor ada 15 fungsi kepemimpinan yang perlu kita ketahui dalam bidang kepemimpinan.

\section{Menyusun Strategi yang Tepat.}

Salah satu fungsi kepemimpinan yang paling penting dan utama adalah menyusun strategi yang tepat. Kepemimpinan yang baik akan membantu grup atau anggota tim dalam menyusun tujuantujuan apa saja yang menjadi prioritas penting.

Strategi juga berperan penting dalam menyusun langkah-langkah apa saja yang harus kita ambil agar bisa lebih mudah meraih tujuan kepemimpinan yang diinginkan.

\section{Merancang Taktik.}

Kepemimpinan sangat identik dengan peluang dan risiko. Nah, disinilah fungsi kepemimpinan memainkan perannya. Salah satu fungsi kepemimpinan akan memudahkan kita untuk merancang taktik yang tepat dalam meraih peluang baru dan mengendalikan risiko yang datang.

\section{Penyelesaian Masalah (Problem Solving).}

Setiap kepemimpinan dalam organisasi atau perusahaan memang tidak akan pernah terlepas dari masalah, masalah dan masalah. Masalah datang untuk dihadapi dan diselesaikan, bukan untuk dihindari. Nah inilah salah satu fungsi kepemimpinan yaitu, menyelesaikan permasalahan dengan solusi yang cepat dan tepat.

\section{Pengambilan Keputusan yang Tepat.}

Fungsi kepemimpinan keempat adalah membantu dalam pengambilan keputusan yang tepat. Seringkali, keputusan yang diambil secara konsensus malah mengarahkan kita pada keputusan yang tidak optimal dan kurang bijak. Dalam hal ini, peran kepemimpinan benar-benar harus bekerja dengan sangat baik, sehingga kepemimpinan berfungsi untuk bersikap adil antara otoritas dan akuntabilitas keputusan. Jika kita berhasil melakukannya, maka kita akan mendapatkan peluang yang lebih besar untuk meraih keputusan yang bijak, optimal dan rasional.

\section{Melakukan Pengorganisasian dengan Teratur.}

Selain itu, kepemimpinan juga berfungsi untuk melakukan pengorganisasian secara teratur. Maksudnya, kepemimpinan berupaya untuk mengatur sumber daya manusia (SDM) agar mampu menyelesaikan tugas-tugas kerjanya dengan hasil yang baik. Pengorganisasian mengatur bagaimana anggota tim harus menggunakan waktu dengan seefisien mungkin dengan menghasilkan karya atau hasil kerja yang lebih banyak. Dengan menerapkan pengorganisasian yang baik, maka semua hal akan menjadi sangat teratur.

\section{Manajemen yang Baik.}

Fungsi kepemimpinan keenam ini hampir sama dengan fungsi kepemimpinan sebelumnya yaitu, pengorganisasian yang teratur. Namun, fungsi kepemimpinan yang keenam ini lebih mengarah pada manajemen yang baik. Dalam manajemen, prinsip kepemimpinan harus mengarahkan dan mengendalikan para anggota timnya ke arah yang benar. Maksudnya, seorang pemimpin harus tahu kemana arah yang benar untuk para anggotanya agar bisa mengejar tujuan bersama. Jika seorang pemimpin tidak bisa menjalankan sistem manajemennya dengan baik, maka bisa dikatakan 
bahwa kepemimpinannya tidak menerapkan fungsinya dengan baik.

\section{Manajemen yang Baik dengan Para Pemangku Kepentingan (Stakeholder).}

Kepemimpinan berfungsi untuk menghubungkan kita dengan para pemangku kepentingan (stakeholder) lainnya. Sehingga ketika kita melaksanakan peran kepemimpinan, kita bisa meminta input atau pengaruh dari pihak-pihak eksternal yang memiliki pengaruh besar pada kepemimpinan kita. Misalnya, memiliki hubungan manajemen yang baik dengan para mitra bisnis.

\section{Membangun Relasi yang Luas.}

Fungsi kepemimpinan lain adalah membantu para pemimpin dalam membangun relasi yang kuat, memperluas network, membina hubungan yang baik, serta menghubungkan satu grup dengan grup lainnya.

\section{Memberikan Pengaruh \& Motivasi yang Kuat.}

Kepemimpinan berfungsi untuk memberikan pengaruh kepada para anggota timnya, serta menularkan motivasi yang kuat kepada mereka, sehingga anggota tim selalu bersemangat dan berambisi dalam mengejar cita-cita bersama. Pengaruh dan motivasi yang kuat dapat diterapkan ke dalam strategi penjualan, taktik dan strategi yang dapat mengajak seluruh lapisan anggota untuk bergerak maju ke arah yang sama dengan memiliki komitmen dan energi yang tinggi.

\section{Manajemen Waktu yang Baik.}

Fungsi kepemimpinan yang kesepuluh akan memudahkan kita dalam memanfaatkan waktu dengan sebijak mungkin. Kepemimpinan berperan untuk mengarahkan kita pada tugastugas yang menjadi prioritas, sehingga kita bisa menyelesaikan tugas-tugas penting tersebut dengan tepat waktu. Dalam hal ini, fungsi kepemimpinan dapat membantu kita dalam meningkatkan produktivitas.

\section{Membantu Mengembangkan Orang Lain}

Kepemimpinan berfungsi untuk membantu para pemimpin dalam mengembangkan wawasan, pengetahuan, pengalaman, dan kemampuan para anggota timnya. Selain itu, pemimpin juga dapat membentuk karakter anggota timnya menjadi lebih baik daripada sebelumnya. Misalnya, mungkin pada sebelumnya, karyawan bekerja dengan sangat lama dan tidak dapat menentukan tugas mana yang harus diprioritaskan. Namun setelah pemimpin menjalankan fungsinya dengan baik, karyawan tersebut bekerja dengan lebih cepat tanpa melewati tenggat waktu dan selalu mengutamakan tugas-tugas penting yang harus didahulukan.

\section{Beradaptasi dengan Perubahan yang Ada.}

Salah satu fungsi kepemimpinan lainnya adalah siap dalam menerima perubahan yang ada. Kepemimpinan yang baik berfungsi untuk beradaptasi dalam perubahan secara cepat, sehingga para pemimpin dapat memberdayakan para agen perubahan dengan sangat baik.

\section{Memimpin dengan Memberi Contoh yang Baik.}

Para pemimpin adalah orang-orang terdepan yang akan diikuti oleh para pengikutnya, sehingga salah satu fungsi kepemimpinan adalah bertindak sebagai contoh yang baik bagi para anggota timnya, terutama dengan menginspirasi mereka menjadi seorang yang beretos kerja tinggi, rajin, berkomitmen dan tangguh.

\section{Membentuk dan Menerapkan Budaya yang Positif.}

Fungsi kepemimpinan lainnya adalah membentuk dan menerapkan budaya organisasi atau perusahaan yang positif kepada para anggota tim atau karyawan, sehingga setiap orang menganut budaya dan pemikiran yang tepat dan positif. Dalam kepemimpinan, fungsi seperti ini sangatlah 
diperlukan untuk membangun norma-norma produktif, harapan, dan makna kehidupan yang dijunjung bersama.

\section{Membentuk Ketangguhan.}

Terakhir, kepemimpinan berfungsi untuk memimpin para anggota tim atau karyawan dengan bersikap tangguh dalam menghadapi segala tekanan, masalah dan kegagalan yang hadir dalam kehidupan. Hal ini bertujuan agar semua motivasi, fokus dan semangat yang kita miliki tidak mudah hilang begitu saja.

\section{PEMBAHASAN}

\section{A. Gaya Gaya Kepemimpinan}

Para ahli telah mengklasifikasikan dan menjelaskan gaya-gaya kepemimpinan, yaitu:

\section{Teori kisi kepemimpinan (blake dan mouton 1964)}

Teori ini mulanya disebut kisi manajerial (managerial grid) tapi kini disebut kisi kepemimpinan . Kisi ini berasal dari hal-hal yang mendasari perhatian manger pada tugas atau pada hal-hal yang telah direncanakan untuk diselesaikan oleh organisasidan perhatian kepada orang-orang dan unsur-unsur organisasi yang mempengaruhi mereka.

\section{Teori 3-D (reddin 1967)}

Tiga dimensi didefinisikan sebagai berikut:

a. Orientasi-kerja. Tingkat pengarahan manjer atas usaha bawahan untuk mencapai tujuan.

b. Orientasi-hubungan. Tingkat hubungan pribadi antara manjer dengan bawahan, ditandai oleh adanya saling mempercayai, menghormati gagasan dan memperhatikan

perasaan

bawahan.

c. Keefektifan. Tingkat persyaratan produksi yang dicapai manajer yang telah ditetapkan.

3. Teori kepimpinan situasional (hersey, 1974 dan blanchard, 1977)

Ada empat gaya kepimpinan situasional yang dikemukakan, yaitu:

a. Gaya 1: memberitahu (telling)

b. Gaya 2: mempromosikan (selling)

c. Gaya 3: Berpartisipasi (participacing)

d. Gaya 4: mewakilkan (delegating)

\section{Teori empat sistem (likert, 1947)}

Likert membagi gaya manajerial tersebut sebagai berikut:

a. Penguasa mutlak (exploitiveauthoritive)

b. Penguasa semi-mutlak (benevolentauthoritive)

c. Penasihat (consultative)

d. Pengajak serta (parcitipative)

\section{Teori kontinum (tannenbaum dan} schmidt, 1957)

Kontinum ini dijelaskan sebagai berikut:

a. Manajer membuat keputusan dan mengumumkannya.

b. Manajer membuat keputusan dan menawarkannya.

c. Manajer mengemukakan keputusannya dan memberi kesempatan untuk mempertanyakannya.

d. Manajer mengemukakan keputusan sementara, yang masih dapat diubah.

e. Manajer menentukan beberapa batasan dan meminta bawahan untuk membuat keputusan. 
f. Manajer mengizinkan bawahan membuat keputusan.

6. Teori kebergantungan (fielder, 1967) Menurut teori kebergantungan, keefektifan pemimpin bergantung pada hubungan-hubungan dalam gaya kepemimpinannya, juga situasi tertentu yang dihadapinya. Jadi, pemimpin ditinjau sebagai bermotivasi-tugas (task-motivated) atau bermotivasi-hubungan (relationship-motivated)

\section{Berdasarkan pendekatan Path-Goal}

a. Gaya Kepemimpinan Direktif (pemimpin pengarah)

Pemimpin seperti ini mengutamakan pemberian pedoman dan petunjuk kepada bawahan bagaimana melakukan pekerjaan serta memberitahukan mengenai apa yang diharapkan dari mereka.

b. Gaya Kepemimpinan Suportif (pemimpin pendukung)

Pemimpin seperti ini memberi pertimbangan atas kebutuhan bawahan, memberi perhatian bagi kesejahteraan dan menciptakan keakraban dengan bawahan dan lingkungan kerja yang menyenangkan.

c. Gaya kepemimpinan partisipatif (pemimpin partisipatif)

Gaya kepemimpinan ini, yaitu beruding dengan bawahan, memberi peluang kepada bawahan untuk memberi masukan berupa saran dan gagasan sebelum mengambil keputusan atau mempengaruhi keputusan yang telah dan akan dibuat.

d. Gaya kepemimpinan yang berorientasi pada prestasi (pemimpin yang berorientasi pada prestasi)

Pemimpin ini menetapkan tujuan menantang, mengupayakan bawahan meningkatkan prestasi, serta mendorong bawahan untuk mencapai tujuan dan hasil karya yang lebih tinggi.

\section{B. TIPE-TIPE KEPEMIMPINAN}

Tipe-tipe dasar kepemimpinan memiliki banyak macamnya seperti salah satunya yang diutarakan oleh Sondang P. Siagian (2002):

\section{1) Tipe Kepemimpinan Otokratik}

Seorang pemimpin yang otokratik ialah seorang pemimpin yang

- Menganggap organisasi sebagai milik pribadi

- Mengidentikan tujuan pribadi dengan tujuan organisasi

- Menganggap bahwa sebagai alat semata-mata

- Tidak mau menerima kritik, saran dan pendapat

- Terlalu tergantung pada kekuasaan formalnya

- Dalam tindaknya penggeraknya sering mempergunakan approach yang mengandung unsur paksaan (bersifat menghukum)

2) Tipe Kepemimpinan

\section{Militeristik}


Seorang pemimpin yang bertipe militeristik ialah seorang pemimpin yang memiliki sifat-sifat:

- Kebanyakan sistem perintah yang sering digunakan

- Senang bergantung pada pangkat dan jabatan

- $\quad$ Senang kepada formalitas yang berlebih-lebihan

- Menuntut disiplin yang tinggi dan kaku dari bawahannya

\section{3) Tipe Kepemimpinan Paternalistik}

Ciri-ciri dari tipe kepemimpinan ini adalah sebagai berikut.

- Menganggap bawahan sebagai manusia yang tidak dewasa

- Bersikap terlalu melindungi

- Jarang memberikan kesempatan kepada bawahannya untuk mengambil keputusan

- Jarang memberikan kesempatan kepada bawahan untuk mengambil inisiatif

- Jarang memberikan kesempatan kepada bawahan untuk mengembangkan daya kreasi dan fantasi

- Sering bersikap mau tahu

\section{4) Tipe Kepemimpinan Kharismatik}

Dalam keadaaan tertentu, tipe kepemimpinan ini sangat diperlukan karena dapat menutupi sifat negatifnya dengan kharisma positif yang dimilikinya..

\section{5) Tipe Kepemimpinan Demokratik}

Pengetahuan tentang kepemimpinan telah membuktikan bahwa tipe pemimpin yang demokratislah yang paling tepat untuk organisasi modern karena:

- Ia senang menerima saran, pendapat dan bahkan kritikan dari bawahan.

- Selalu berusaha mengutamakan kerjasama teamwork dalam usaha mencapaitujuan.

- Selalu berusaha menjadikan lebih sukses dari padanya.

- Selalu berusaha mengembangkan kapasitas diri pribadinya sebagai pemimpin.

6) Tipe Kepemimpinan Laissez Faire

Tipe kepemimpinan yang santai dan pengambilan keputusan diserahkan kepada para bawahannya dengan pengarahan yang minimal bahkan tanpa pengarahan sama sekali. Oleh karena itu, tipe kepemimpinan ini sering kali dianggap sebagai seorang pemimpin yang kurang memiliki rasa tanggung jawab yang wajar terhadap organisasi yang dipimpinnya. Serta memandang dan memperlakukan bawahannya sebagai orang-orang yang sudah matang dan dewasa, baik dalam teknis maupun mental

\section{PENGARUH}

GAYA

\section{KEPEMIMPINAN}

Gaya kepemimpinan yang diterapkandalam organisasi, apapun bentuk kepemimpinannya akan mempengaruhi cara orang bekerja sebagai individu atau sebagai kelompok. Dalam kenyataannya pemimpin dapat mempengaruhi semangat dan kegairahan 
kerja, keamanan, kualitas kehidupan kerja dan terutama tingkat prestasisuatu organisasi. Hubungan antara gaya kepemimpinan dengan kinerja karyawan adalah linier artinya bahwa gaya kepemimpinan berpengaruh positif dan signifikan terhadap kinerja karyawan secara langsung. Hal ini menjelaskan bahwa adanya gaya kepemimpinan yang demokratis yaitu keterbukaan terhadap saran, kritik dan pendapat dari bawahan sehingga pimpinan mampu menghasilkan keputusan yang dapat meningkatkan kualitas kerja karyawan . Salah satu keputusan yang diambil oleh pimpinan yaitu memberikan kebebasan dalam bekerja bagi karyawan, di mana kebebasan dalam bekerja ini mampu mendorong karyawan untuk meningkatkan kuantitas produk/jasa yang dihasilkan yang berdampak terhadap kepuasan pelanggan.

Dengan kata lain kinerja karyawan akan meningkat sejalan dengan perbaikan gaya kepemimpinan . Kepemimpinan berarti kemampuan untuk mempengaruhi, menggerakkan, dan mengarahkan suatu tindakan pada diri seseorang atau sekelompok orang untuk tujuan tertentu. Dalam upaya mempengaruhi tersebut seorang pemimpin menerapkan gaya yang berbeda-beda dalam setiap situasi.

\section{KESIMPULAN}

1. Terdapat pengaruh antara gaya kepemimpinan dalam organisasi karena dapat mempengaruhi cara orang bekerja sebagai individu atau kelompok, kemudian disini pemimpin sangat berpengaruh karna fungsinya sebagai penggerak, penyemangat, dan otak utama dari suatu program yang ia pimpin.

2. Terdapat berbagai macam gaya-gaya memimpin. Semua gaya kepemimpinan itu masing-masing memiliki ciri tersendiri dan itulah yang menjadikan seorang pemimpin dapat memimpin kelompoknya dengan caranya sendiri yang pastinya akan bertujuan sama seperti pemimpin pada umumnya yang ingin mempengaruhi orang untuk melakukan tindakan yang bermanfaat bagi organisasi dan dirinya sendiri untuk mencapai tujuan tertentu

\section{DAFTAR PUSTAKA}

Adam Ibrahim Indrawijaya,1986, perilaku organisasi, sinar baru: Bandung,

Agusman. 2004.Pengaruh Gaya Kepemimpinan, Motivasi dan Lingkungan KerjaTerhadap Kinerja Sekretariat Daerah Kabupaten Kepulauan Riau. TesisProgramPasca Sarjana Magister Manajemen Universitas Gajah MadaYogyakarta

Dwijanto Agus ,dkk, 2006. Reformasi Birokrasi Publik di Indonesia

.Yogyakarta: Gadjah Mada University Press

Isran Noor, 2012. Politik Otonomi Daerah untuk penguatan NKRI. PT.Profajar Jurnalism.

https://ruangguruku.com/pengertiankepemimpinan-menurut-para-ahli

https://www.studilmu.com/blogs/details/pe ngertian-fungsi-kepemimpinan-dan15-fungsi-kepemimpinan 
http://id.wikipedia.org/wiki/Kepemimpina nhttp://www.membuatblog.web.id/20 10/05/kepemimpinan-dalamorganisasi.html

Http://Www.Academia.Edu/4984126/Anal isis_Analisis_Pengaruh_Gaya_Kepem impinan_Motivasi_Dan_Lingkungan_ Kerja_Terhadap_Kinerja_Pegawai

Lijan Poltak Sinamela, dkk, 2006. Reformasi Pelayanan Publik : Teori Kebijakan dan Implementasi. Jakarta: Bumi Aksara.

Media Sewaka Dharma, 2012. Pelayanan Publik Berbasis Kearifan Lokal,Denpasar : Bagian Organisasi Setda Kota Denpasar.
Radiq. 1998. Manajemen Sumber Daya Manusia.. Badan Penerbit IPWIJakarta.

Robbins, Stephen. 1996.Perilaku Organisasi Konsep: Kontrover Aplikasi, Jilid 1dan 2, PT. Prenhallindo, Jakarta

Syamsuddin Haris, 2005. Desentralisasi dan Otonomi Daerah: Desentralisasi, Demokratisasi dan Akuntabilitas Pemerintahan Daerah.Jakarta : LIPI Press.

Undang-Undang Republik Indonesia Nomor 23 Tahun 2014 tentang Pemerintahan Daerah.

a. Undang-Undang Republik Indonesia Nomor 29 Tahun 2009 tentang Pelayanan Publik. 